\title{
曳航式サブボトムプロファイラーを用いた海底熱水鉱床 に打ける音響搩查技術の開発
}

\author{
三尾有年 $(\mathrm{NTT} \text { データ } \mathrm{CCS})^{* 1, \dagger}$ ， \\ 浅田 昭, 水野勝紀, 片瀬冬樹, 小島光博 (東京大学生産技術研究所) *2 \\ (2016 年 3 月 31 日原稿受付)
}

\section{Abstract:}

In order to assess hydrothermal deposits within the Japanese Exclusive Economic Zone to secure domestic marine mineral resources, we are developing and using five observation devices: Multi-Beam Echo Sounder (MBES), Sub-Bottom Plofiler (SBP), Remotely Operated Vehicle (ROV), Interferometric Synthetic Aperture Sonar (InSAS), and samplers. Although topography can be determined with an ROV and/or InSAS, the accurate identification of submarine hydrothermal deposits requires a detailed observation of the geological structures underneath the vents. To this aim, we developed an SBP to perform detailed and geocoded surveys of zones previously mapped at a rough scale with MBES. Our SBP can observe vents as large as several tenths of meters. Its airfoils help suppress roll, and its arrays of 8-channel acoustic receptors reduce noise. Chirped signals allow a resolution in depth of $3.75 \mathrm{~cm}$, which we believe should be sufficient to analyze hydrothermal vents.

Surveys over submarine calderas of the Izu-Bonin island arc were carried out in July 2014 with our SBP. On the Bayonnaise reef, we determined the structure down to $30 \mathrm{~m}$ below the seafloor.

In the future, our devices could be used to determine the geological structures of hydrothermal vents in other hydrothermal zones.

Classification: 物理音響・海底音響, 信号処理

Keywords: 曳航式サブボトムプロファイラー, 海底熱水鉱床, 音響探査

1.はじめに

日本周辺海域では有望な海底熱水鉱床等の海洋
鉱物資源が確認されている。しかし, 海洋基本計 画 $^{1)}$ で目標に掲げられている平成 30 年後半の商

Development of the Acoustic Research Technology with the Towed Sub-Bottom Profiler for the Discovery of Submarine Hydrothermal Deposits

* 1 Aritoshi MIO (NTT DATA CCS CORPORATION)

*2 Akira ASADA, Katsunori MIZUNO, Fuyuki KATASE, Mitsuhiro KOJIMA (Institute of Industrial Science, The University of Tokyo)

$\dagger$ amio@nttdata-ccs.co.jp 
業化を実現するためには，より大規模で採掘コス 卜に見合う鉱床の発見が必要不可欠となる。最近 では，活動中の熱水鉱床のほかに活動を終えた熱 水鉱床 (非活動的熱水鉱床) や熱水活動の終了後 に堆積物に覆われ現在は海底面上に露出してい ない鉱床 (潜頭性鉱床) の存在が期待されている. しかし, 非活動的熱水鉱床や潜頭性鉱床の探査技 術はまだ確立されていない.

本研究グループでは，海洋鉱産資源の確保のた めに我が国の排他的経済水域内にある熱水鉱床を 探索することを目的として，海洋鉱物資源広域探 查システムの開発を行い，下記に示すように広域 的な音響探査から局所的な岩石のサンプリングま での幅広いレンジの観測ツールを用いて海底熱水 鉱床の絞り込みを行っている.

・MBES による広域での地形・反射強度マップ の作成

・SBP (サブボトムプロファイラー) 曳航体によ る海底下探査

・ROVによる海底探査

- InSAS 搭載の Autonomous Underwater Vehicle (AUV)による精密三次元音響画像計測

・柱状採泥・岩石コアサンプラーによる海底採取 調査対象は，大きく 3 つのカテゴリー（広域調 查, 中域調查, 詳細調查) に分けられ, 広域調查 を MBES，中域調査を SBP, ROV および合成開 ロソーナー, 詳細調査を柱状採泥と位置づけて いる. 中域調査の中で ROV や合成開ロソーナー は，海底の表面の観測を行ううえでは，重要な役 割を果たすが, 海底下の地下構造を知るためには, SBP による音響探査が必須となる。

一般に SBP は, 海底下数十 $\mathrm{m}$ の地層の構造を 調査することを目的とするもので海底工事の事前 調査, パイプライン埋設のためのルーティング調 查などに用いられる. 研究対象としては, 湖沼や 海底の堆積層の層厚を求める研究 ${ }^{2-4)}$ が多数存在 する。また，海洋鉱物資源調查に適用する場合 は，船に設置したSBP を用いて広域的に調査を 行う場合が多い。しかし，SBPによる広域的な調
査では海底までの距離による減衰や音波の指向性 の問題から熱水鉱床下の精密な地下構造を得るこ とは困難である。これに対して曳航体や AUVを 使って海底に接近して音響探査 ${ }^{5,6)}$ を行えば, 海 底熱水鉱床の精密情報をピンポイントで確定する ことが可能となる. そこで, 本研究グループで は，海底熱水鉱床の発見のための確度を上げるた めのツールの 1 つとして曳航式の SBP の開発を 行った(以降 SBP 曳航体). SBP 曳航体による探 査の目的は, 熱水鉱床の地下構造の観測であるた め, 深海でも安定した観測を行うために曳航体の 強度, SBP 曳航体の位置精度の確保, 受信デー 夕の精度, 観測中の SBP 曳航体の姿勢を考慮に 入れて曳航体を開発した。

本研究では, 2014 年 7 月に伊豆小笠原諸島の ベヨネーズカルデラにおいて音響探査を実施した 観測手法および観測結果 (音響画像断面マップ) を示す。また，音響画像を作成するうえで影響を 受けるノイズ (通信機器, 送信器, 多重散乱)に ついて低減手法を開発し, 適用した。

\section{2. 観測}

\section{1 観測地域}

本研究航海では, 2014 年 7 月に実施した $\lceil$ KKKyot14-03-Sumisu」航海においてベヨネーズ カルデラの観測を行った. Fig. 1 に調査海域エリ アを示す. Fig. 2 にベヨネーズ海丘内で実施した SBP 戔航体の観測側線を示す。本観測では, カ ルデラの東側スロープから進入し, カルデラの底 を経てカルデラの西側スロープを登る経路をと り，SBP 曳航体によってカルデラの断面を観測 した. なお, 本研究では, 既存の熱水鉱床の地下 構造の把握のためにベヨネーズ海丘カルデラの東 側斜面に位置する白嶺鉱床の上を通るルートを選 定した。

\section{2 観測機器}

SBP 曳航体は, SBP 本体と海底下の層厚構造 を探査するセンサー群を搭載している，以下に曳 航体および搭載されている観測機器について説明 
する。

(1) 曳航体の形状

Fig. 3 の曳航体の配置図が示すように SBP 曳 航体の先頭部は, 水の抵抗を少なくするために流 線型の形状をしている. 曳航するワイヤーは, 曳 航体の真上に設置され, 船からワイヤー操作が行 われる. ワイヤーの長さは, 数百 $\mathrm{m}$ に達するため, 曳航体自体の安定性が求められ，特に横摇れの影 響を受けないために水平尾翼および垂直尾翼を付

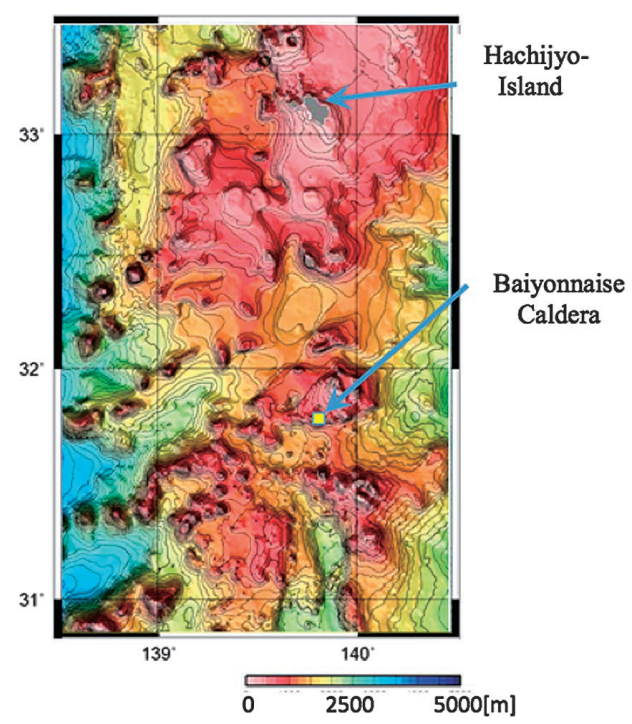

Fig. 1 Research sea area.
加した。 これまでの観測において姿勢情報のログ を確認する限り曳航体自体の横摇れやそれに伴う デー夕処理の欠損は, 発生しておらず, 安定した 観測を行っている.

(2) 音響観測装置

Table 1 に示す通り水深 $3000 \mathrm{~m}$ まで潜行可能で ある。音波探査デー夕の計測システムは前方に音 波探査用の送波音源(無指向性), 中腹部上方に音 波送信用のパワーアンプ等を格納した音波探査用 アンプシリンダ耐圧容器, 中腹部下方に CPU ボー ドや音波デー夕収録装置, システム駆動用電池を 格納した音波探査用回路シリンダー耐圧容器を搭 載している.

(3) 音響モデム

SBP 曳航体の位置情報を船上にリアルタイム で知らせるため, 本システムでは, SBP 曳航体 と通信用の曳航体(通称 FISH) の通信および, 船 に設置された GAPS (Global Acoustic Positioning System) と SBP 曳航体の通信を SBP 曳航体に設 置された音響モデムを通じてそれぞれ 2 系統の通 信を行っている。 今回の航海の場合, SBP 曳航 体と通信用の曳航体との距離が離れると通信不能 になることがあったため, 曳航体のワイヤー操作 は，主にGAPS から得られる位置情報を用いて

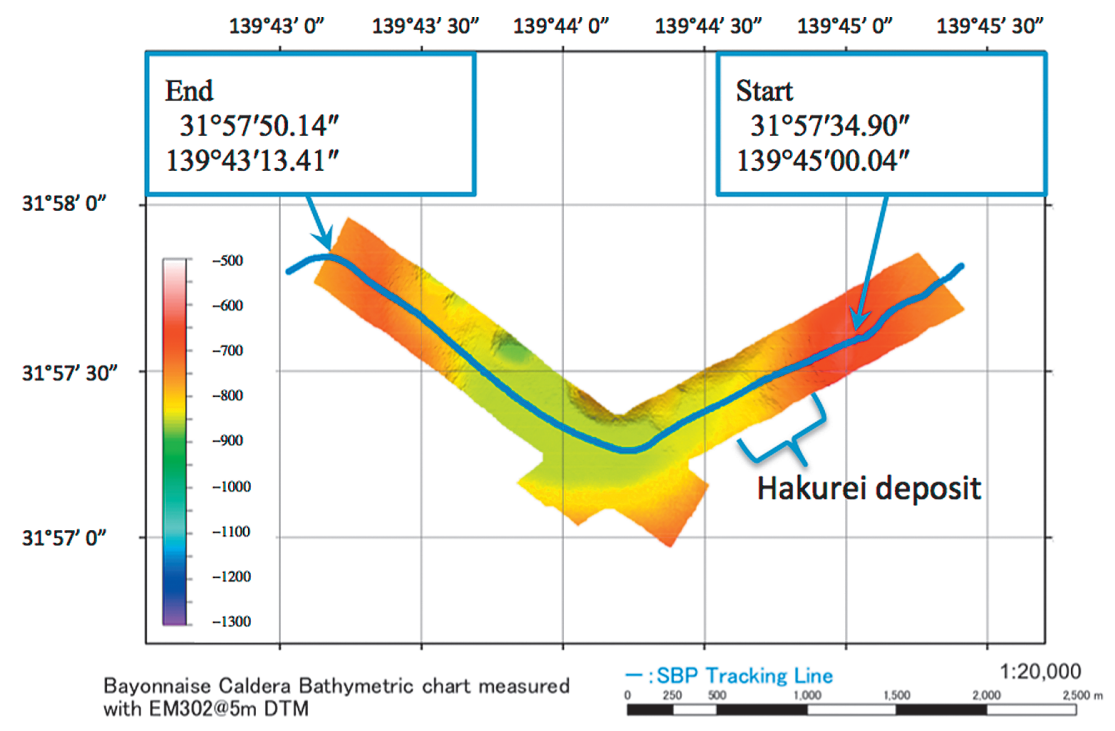

Fig. 2 SBP tracking line in Bayonnaise Caldera. 

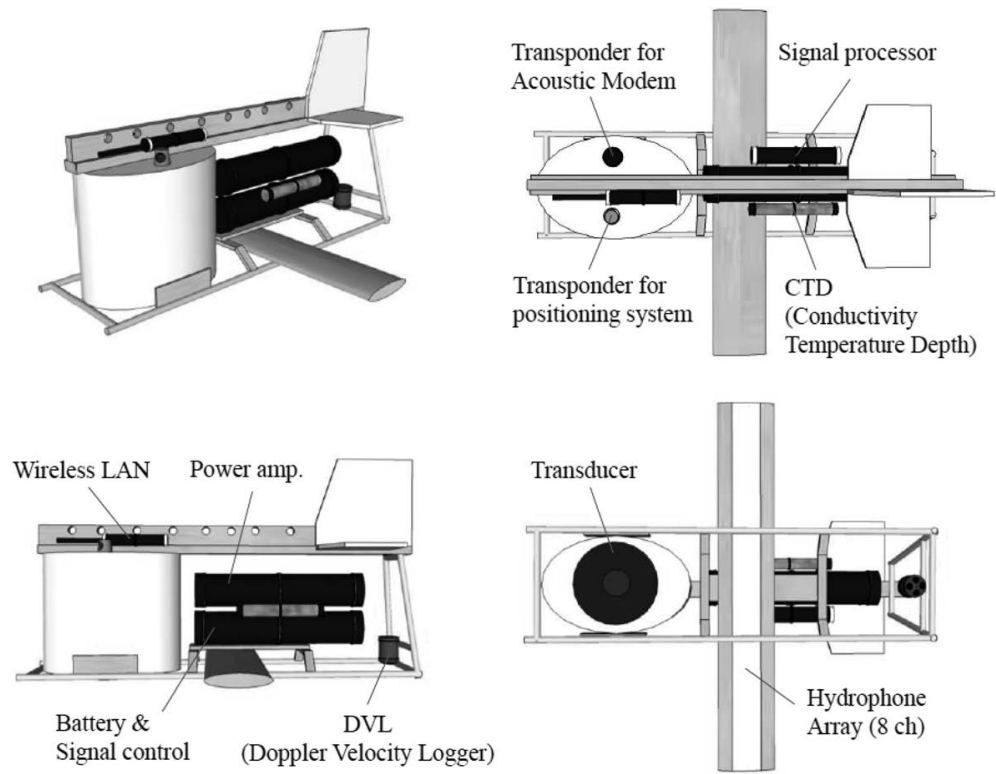

Fig. 3 Towed SBP system.

Table 1 Performance of SBP.

\begin{tabular}{lc}
\hline \multicolumn{1}{c}{ SBP features } & Value \\
\hline Dimensions & $2.9 \times 2.6 \times 1.5 \mathrm{~m}$ \\
Weight & $500 \mathrm{~kg}$ \\
Maximum Voltage & $1.75 \mathrm{kV}$ \\
Maximum Operational Depth & $3,000 \mathrm{~m}$ \\
Duration of battery & $8.0 \mathrm{~h}$ \\
Sensors & DVL, GAPS, Acoustic \\
& Modem CTD \\
\hline
\end{tabular}

行った.

(4) 海中運用環境の計測システム

- Doppler Velocity Logger(DVL)（Nav Quest 600） 曳航体の後部に設置されており, 曳航体の速度, 加速度, 曳航体の高度を計測し, 曳航体の位置, 姿勢情報を取得しており，この情報は，音響モデ ムを通じて船にリアルタイムで送信されている。

- Conductivity Temperature Depth profiler (CTD) (Citadel CTD-NV)

曳航体の後部側面に搭載されており, 電気伝導 度, 水温, 水深を観測している。 この水深情報は, 3.1.4の CTD 高さ補正の処理で使用され, SBP 曳航体から反射面までの距離情報しか持たない音 響デー夕を海面からの距離に変換するために使用 される。
（5）トランスデューサ (Echoes-1500, IXSEA)

音響計測は, 送波音源から曳航体下方の海底に 対して低周波音波を発信した後, 海底下へ浸透し た音波が熱水鉱床などの薄層境界面からの反射波 を収録する。ハイドロホンアレイは，8 チャンネ ル装着されており, 電気ノイズをキャンセルする ために奇数チャンネルと偶数チャンネルで極性を 逆転させて音響デー夕を収容している.

音波探査のシステムは, 送信波として電圧を $1.75 \mathrm{kV}$ まで引加することができ, $1.2 \mathrm{kHz}$ を中心 とし, 幅 $0.5 \mathrm{kHz}$ の広帯域チャープ信号を使用し て海底下反射波の観測分解能を向上させている.

\section{3 観測方法}

Fig. 4 に観測概念図を示す。まず，調查船から ワイヤーで繋いだ SBP 曳航体を海底からの高度 50-100m まで下ろし, 高度を維持しつつ, 等速 (約 $1 \mathrm{~m} / \mathrm{s}$ ) で铍引した。また，船から音響モデム を搭載した別の曳航体を海面から 10-15 m 程度 の深さに沈め牽引した。この FISH 曳航体の役割 は, SBP 曳航体から送信される DVL 高度情報 やCTD 深度情報を受信し, 通信ケーブルを通じ て船に送信することである，船上では曳航体と海 底との高度をモニタリングしながら船の操船(ワ 


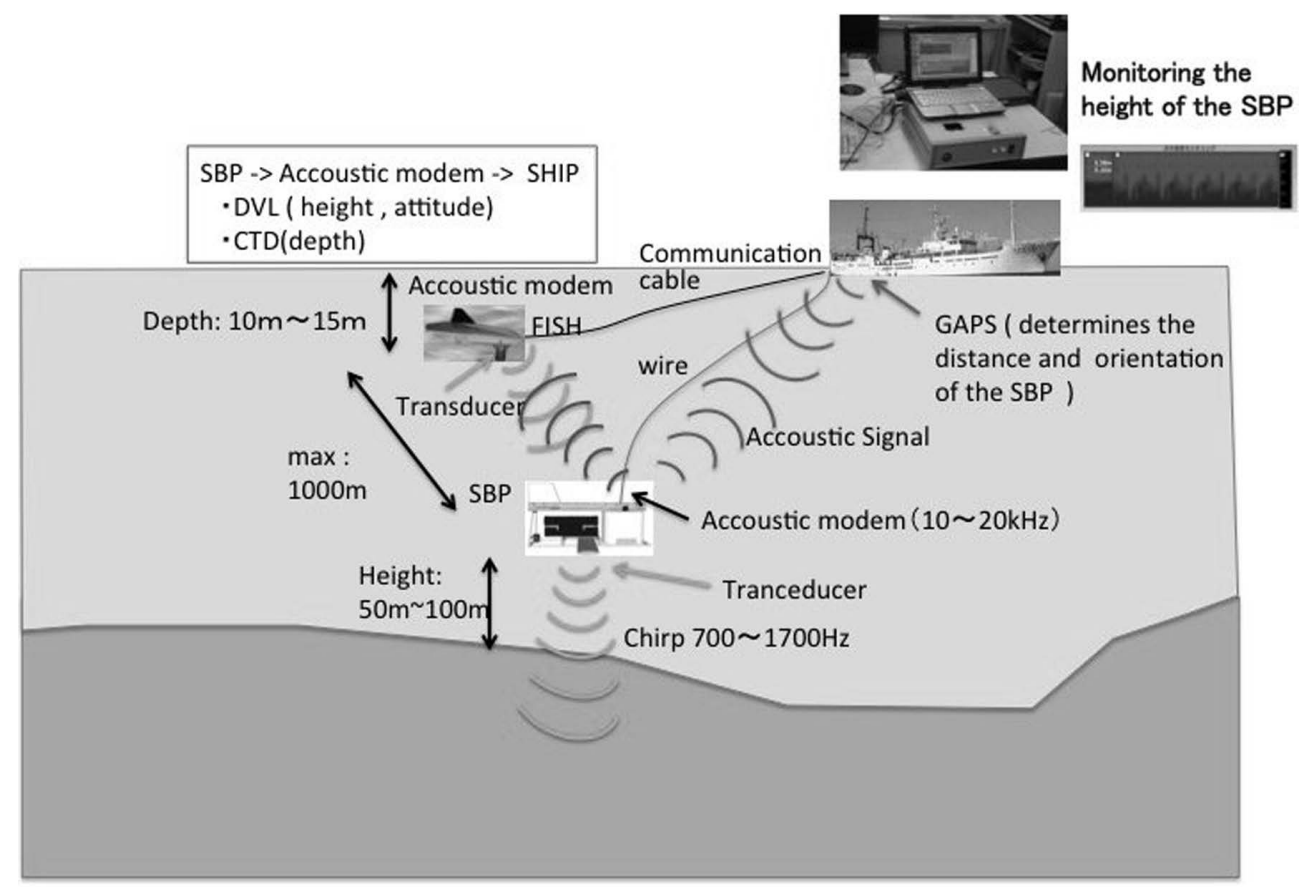

Fig. 4 Conceptual diagram of SBP research.

イヤーの出し入れ)を行った.

ただし，SBP 曳航体と FISH 曳航体との間の通 信が途絶えた場合は，調査船に設置された GAPS によって SBP 曳航体の位置情報を取得し, 高度 の維持を行った。

\section{3. デー夕解析}

\section{1 解析手法}

水中での残響ノイズの除去は, ハード面では, 音波の指向性を高めて残響の受信を抑えるもの や, TVG の使用によって残響の低減をはかる などの手法があげられ，本システムでも受信回路 に TVGを用いて残響の低減を行っている. しか し，海面反射や壁面反射などで音響画像に写り こんだノイズの除去は, 容易ではない.これは, ソーナーの指向性や姿勢, 海底地形の反射が厳密 にシミュレーションできないためである。実際, 音響画像の多くは，残響に関しては，そのまま残 し，残響であることを提示して除去しない例 ${ }^{8)}$ が 多い.しかし，今後新たな熱水鉱床を発見するた めにグランドトゥルースデータのないエリアに対
して音波探査を行った際に残響の除去または低減 を行うことは, 地下構造の把握を行う上で必要不 可欠となる。 そこで, 本研究では, 音響画像に対 するフィルターの適用を行ったＳSBP曳航体の 受信データから音響断面マップを作成するまでの 解析処理の手順を Fig. 5 に示す. 以下, 各解析を 概説する.

\subsection{1 チャネル合成}

本研究では, より高精度の音響画像を取得する ために複数の受信チャネルから得たデータのス タッキングを行っている.

まず, SBP 曳航体から海底に向けて音波を発 射し,さまざまな場所から反射してきた音響信号 を 8 チャンネルのハイドロホンで受信する.この とき, 電気信号のノイズをキャンセルするため, ハイドロホンの奇数と偶数の極性を反転させてい る. データ処理では, 8 チャンネルのデータを読 み込み，極性を合わせたうえで Eq. (1)のように 合成した。 
合成チャンネル $=\operatorname{ch} 1+(-1) * \operatorname{ch} 2+\operatorname{ch} 3$

$$
\begin{aligned}
& +(-1) * \operatorname{ch} 4+\operatorname{ch} 5+(-1) * \operatorname{ch} 6 \\
& +\operatorname{ch} 7+(-1) * \operatorname{ch} 8
\end{aligned}
$$

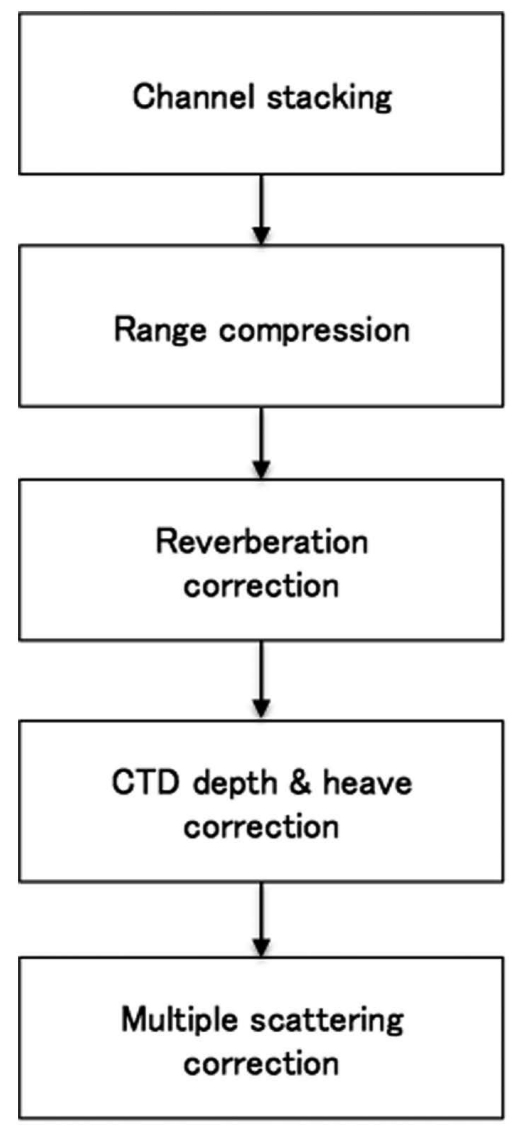

Fig. 5 Flow chart of SBP data analysis.

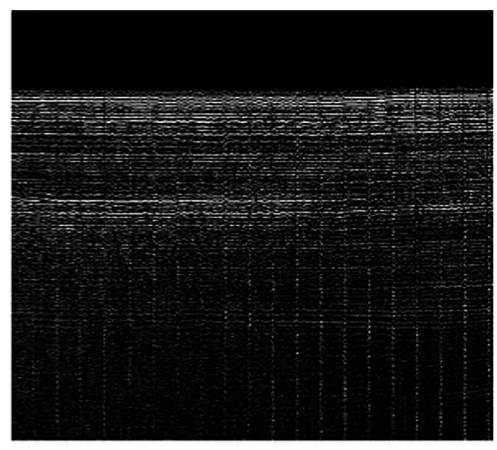

(a) Acoustic image using ch8 only
ここで, 1 チャンネルのみで結像した結果 $(\operatorname{ch} 8$ を使用)と 8 チャンネルすべてをスタッキングし た結果を Fig. 6 に示す。ここでは明らかに右図の 方がノイズの低減化していることがわかる. 左図 で発生している上下方向のストライプノイズは, 単チャンネルで画像を結像した時, Fig. 3 の史航 体の両羽根の部分に位置する $1,2,7,8$ チャンネ ルでレンジ方向(鉛直方向)に20秒間隔で発生し ている.この原因は, 曳航体の上部に搭載されて いる音響モデムが 20 秒間隔で通信を行っている ためと考えられる。一方, 曳行体の腹部に位置す る 3, 4, 5, 6 チャンネルにストライプノイズが混 入しなかった原因は, 八イドロホンの位置が曳航 体の陰となったためと考えられる.

\subsection{2 レンジ圧縮}

SBP 曳航体から発射する送信パルスは，700$1700 \mathrm{~Hz}$ の FM 変調がかけられている. 一般に帯 域幅を $N$ 倍すると元の送信波の長さの $1 / N$ の短 いパルスを発射したことと等価となり, 距離分解 能を $N$ 倍に上げることが可能となる。 この手法 は, 衛星 SAR の合成開口処理でも使用されてお り, レンジ圧縮処理 ${ }^{9)}$ と呼ばれる.

FM 変調をかけたチャープパルスは, Eq. (2) で定義される。本研究では, チャープ幅を $700 \mathrm{~Hz}$ から $1700 \mathrm{~Hz}$ に変化させている.

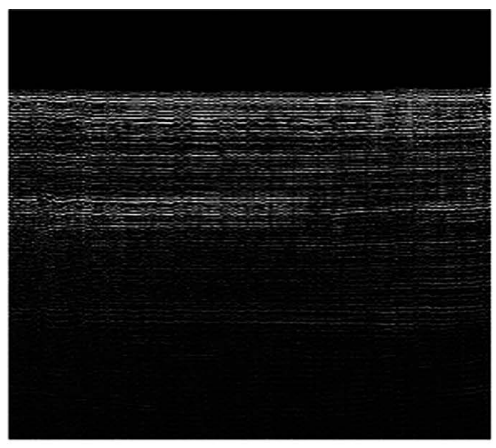

(b) Acoustic image using 8 channels

Fig. 6 Channel stacking. 


$$
\begin{gathered}
r(t)=\sin \left(2 \pi *\left(\mathrm{f} 0+(\mathrm{f} 1-\mathrm{f} 0) /(2 T)^{*} t\right)\right. \\
\mathrm{f} 0: \text { 開始チャープ值 } \\
\mathrm{f} 1: \text { 終了チャープ值 } \\
T: \text { シグナルの長さ }
\end{gathered}
$$

Eq. (2) は，送信信号のチャープパルスである. この信号の FFT と海底下からの反射信号 Rsig の FFTの共役を取り，逆FFTを施して実空間上に 戻すことで, 音響画像を結像させることができる. Eq. (3)に周波数空間上の相関処理を示す.

$$
\operatorname{sig}(t)=\operatorname{invFFT}(\operatorname{FFT}(r(t)) * \operatorname{FFT}(R \operatorname{sig}(t)))
$$

FFT : 高速フーリエ変換

invFFT: 逆高速フーリエ変換

$r(t) \quad:$ リファレンスチャープ信号

$R \operatorname{sig}(t)$ : 受信信号

本研究では, 1 ピングごとに Eq. (3) の処理を 施し, 解像度の向上をはかった.

Fig. 7 にレンジ圧縮前後の結果を示す. Fig. 7 左側のレンジ圧縮前においては, レンジ方向(鉛 直方向) のフォーカスが甘くなっているのに対し
て, 右側のレンジ圧縮後の結果は, レンジ方向に フォーカスが合い, 特に斜面でピークが揃ってい ることがわかる.

\subsection{3 ストライプ残響補正}

Fig. 7 のレンジ圧縮前後の画像に Azimuth 方向 (水平方向)のストライプノイズが残存している. これは，SBP 曳航体のトランスデューサ自身の 残響ノイズであり，音波を発射した後にも残るた め $8 \mathrm{ch}$ のハイドロホンは, 近くの発信源の残響 を反射波とともに受信する。しかし，このノイズ は, トランスデューサの特性に起因するためピン グごとに異なった残響は発生せず, SBP 曳航体 からの距離に伴って同じパターンの残響が出力さ れる. そこで, このレンジ方向に同様の残響が発 生する特徵に着目し，レンジ方向に信号をスタッ キングし，それをリファレンスとして，元の信号 にフィッティングして差分を取ることにより，ス トライプ残響ノイズの低減を行った.

ストライプ残響ノイズ除去の概念を Eq. (4)に 示す. ここで, $x$ を曳航体の進行方向, $y$ を音波 の発射方向とする.

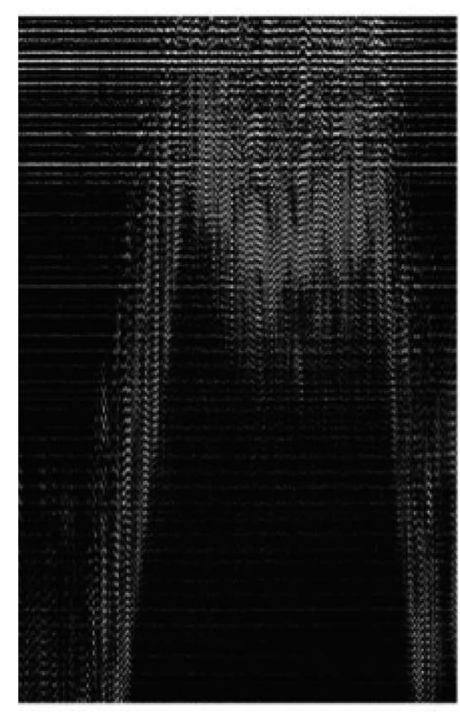

(a) pre-range compression

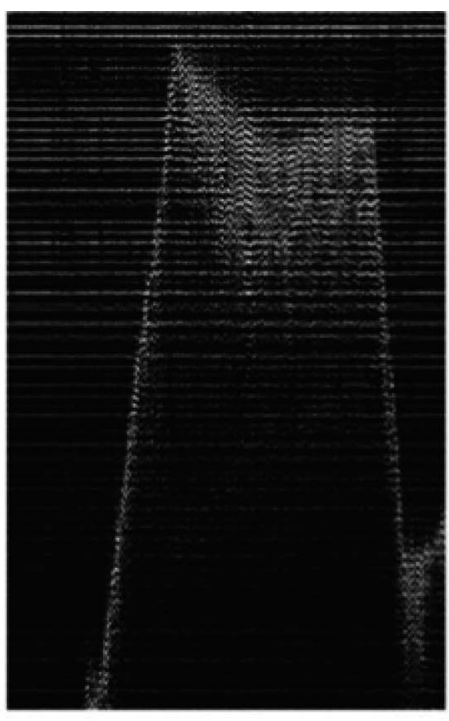

$100 \mathrm{~m}$

Fig. 7 SBP acoustic image with range compression. 


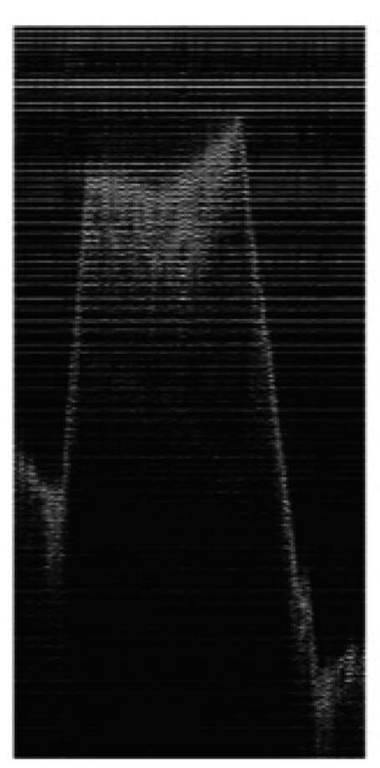

(a) range compression

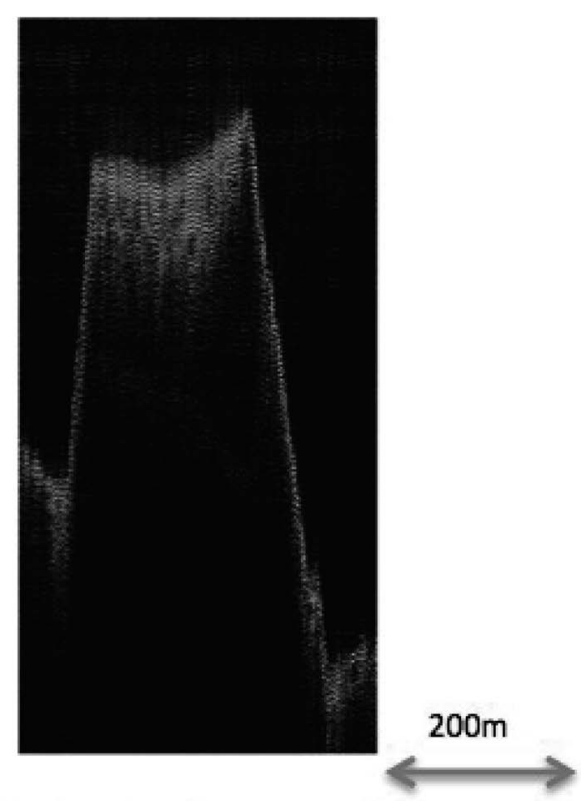

(b) reverberation correction

Fig. 8 SBP acoustic image with reverberation correction.

$$
\mathrm{S}^{\prime}(x, y)=\mathrm{S}(x, y)-\operatorname{mean}(y)
$$

$\mathrm{S}^{\prime}(x, y)$ : ストライプノイズ除去後の出 カシグナル

$\mathrm{S}(x, y)$ : レンジ圧縮後の入力シグナル $\operatorname{mean}(y)$ : 進行方向のシグナルの平均值

Fig. 8 にストライプ残響ノイズ補正の結果を示す. ストライプノイズを除去する前後の画像を見ると, Fig. 8 の右側のストライプノイズ除去後の画像で は, 水平方向のノイズが十分に除去できているこ とがわかる．また，ストライプノイズと交差する 斜面の反射輝度は，そのまま残っており，ストラ イプノイズの除去によって過剩除去が起こってい ないことがわかる。

\subsubsection{CTD 深度・ヒーブ補正}

残響補正までの処理においてレンジ方向 (鉛直 方向) の距離は, 曳航体からの距離を示している. そこで正しい海底面の地形を抽出するために母船 から曳航体までの距離を CTDによって計測され た值を加えて相対的な海底地形の変化量に変換す る高さ補正を施した。しかし， CTD 深度補正を 行っただけでは，海底面の凹凸(数 $\mathrm{cm}$ 一数十 $\mathrm{cm}$ )
残るため, 海底面に強い反射面が存在し, それが 曳航体の進行方向に連続しているという仮定のも とにヒーブ補正を行った。 本研究では, 海底面付 近で最も反射強度が強い範囲を進行方向に該当ピ ング数分抽出し, その移動平均を取り, 移動平均 線に元の反射面が並ぶように上下方向にピクセル の移動を行った.

Fig. 9 に高さ補正の結果を示す. Fig. 9 の左側 のヒーブ補正前の画像では, 海水と海底面の境界 がぼけている.これに対して右側のヒーブ補正後 は，画像上面に強い反射面が二層確認することが でき,その下の層状構造もはっきりと確認できる.

\section{1 .5 海底下深部の多重散乱の低減}

本研究で SBP 曳航体に搭載した送波音源は, 無指向であるためあらゆる方向からの反射を取得 する可能性がある。斜度が急激に変化する場所で は, 多重散乱によるノイズが地下の深い場所に重 畳し, あたかも地層構造が存在するかのように結 像する。この多重散乱を低減するために，音波が 距離の二乗に反比例して減衰することを利用し, 多重散乱低減フィルターを SBP 曳航体音響画像 に対して適用した。 

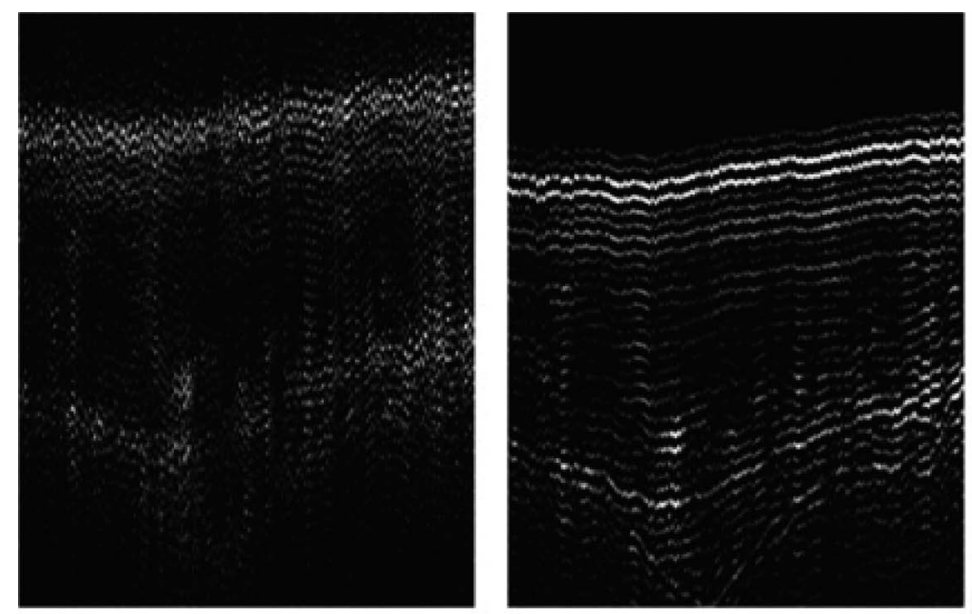

$50 \mathrm{~m}$

(a) CTD correction (b) CTD + heave correction

Fig. 9 CTD height and heave correction.
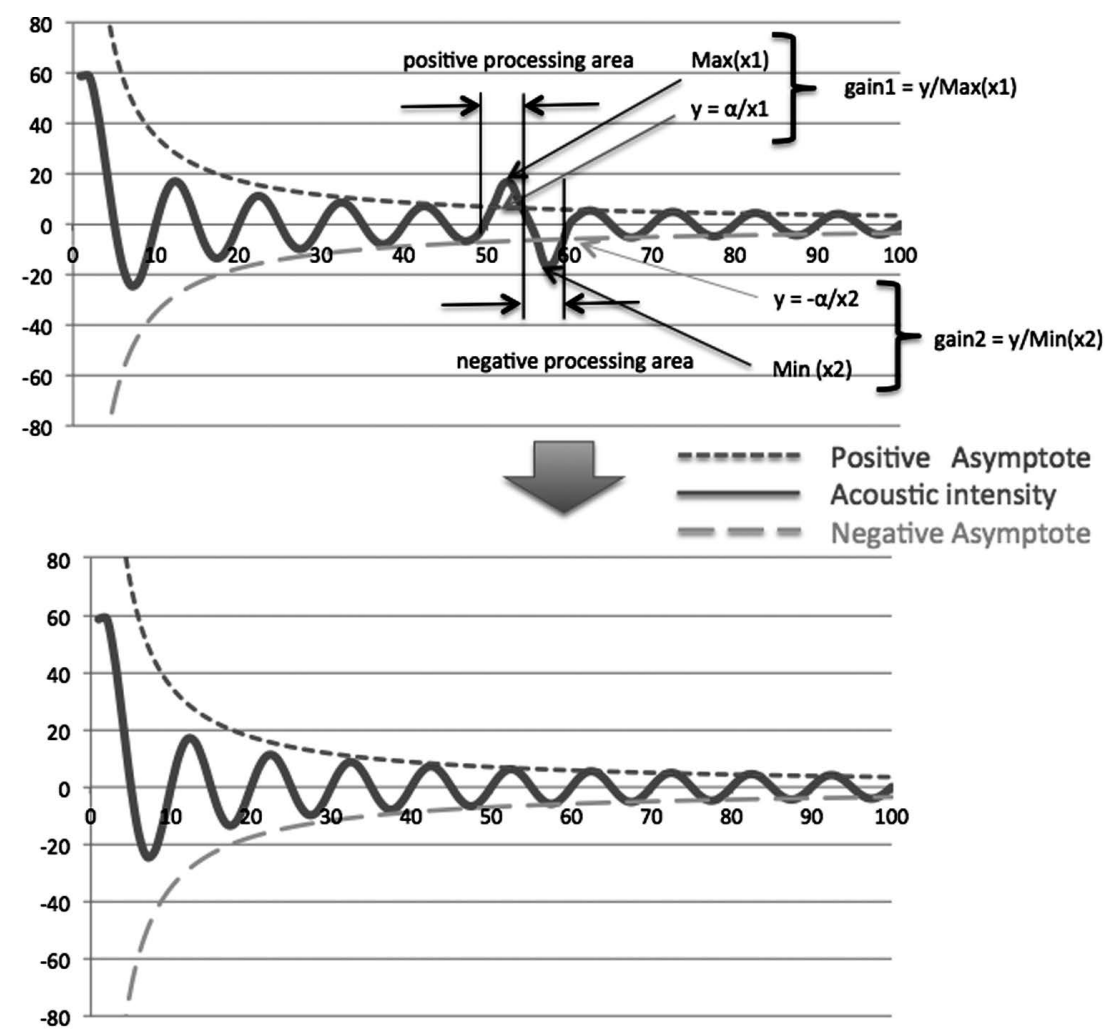

Fig. 10 Conceptual diagram of multichannel reverberation depression.

通常音波は，距離が遠ざかるにしたがって減衰

するが，多重散乱が発生した場合，Fig. 10 に示

すような強度異常が発生する。，そこで，反射強度 の極大值 (もしくは極小值)の漸近線を以下の式
で定義した。

$$
y=\alpha / x^{2}
$$




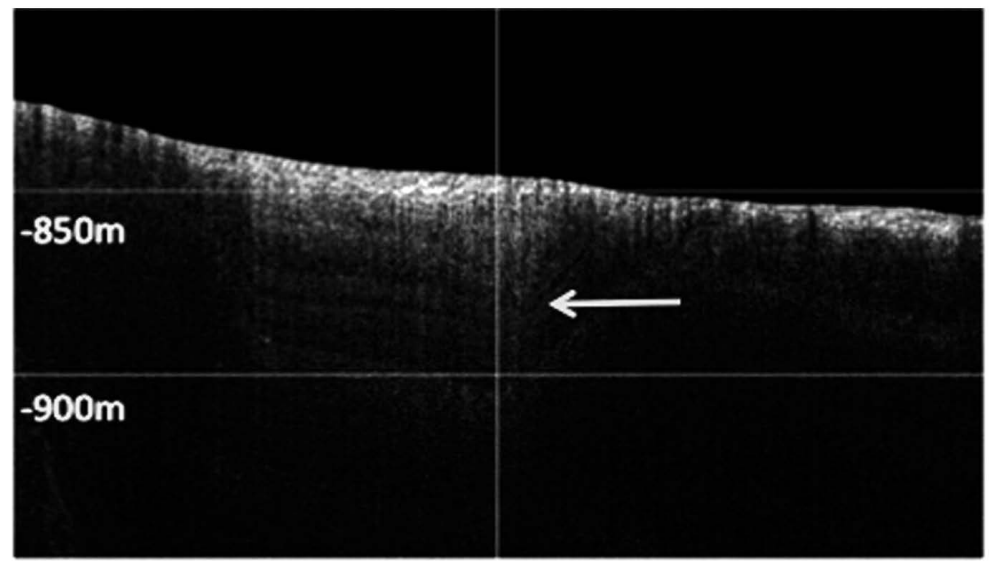

(a) no correction image

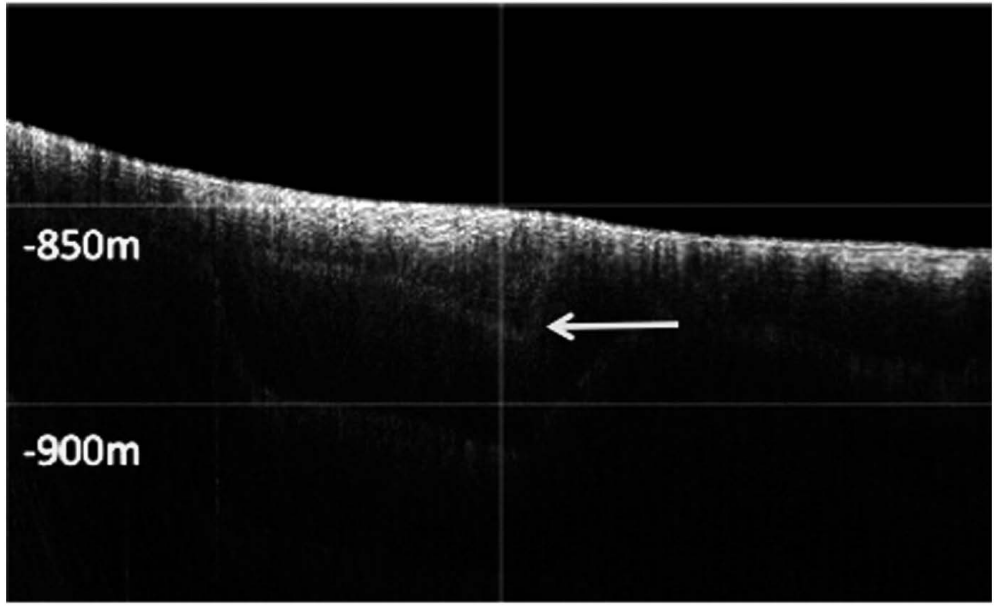

(b) correction image

Fig. 11 Application results in using multichannel reverberation depression.

$x$ は海底から下方のピクセルまでの距離, $\alpha$ は 解析エリアの強度の最大值を設定した。 また，漸 近線を超える值を異常值として異常值の最大值が 漸近線を超えないようにゲインを調整する処理を 施した。ただし，漸近線を超えるエリアのみゲイ ンを掛けると画像に不連続が生じるため, $y$ の值 が 0 から極大值となり，極大值から 0 に戻る範 囲に対してゲインを設定した。この処理の結果を Fig. 11 に示す. 多重散乱の低減補正前の画像は, 多重散乱により深度 $50 \mathrm{~m}$ までの信号が確認でき るが, 補正を行うことにより大幅に改善されてい ることがわかる.ただし, Fig. 11の下の画像では, 海底下に層状の構造(図中の矢印部分) が確認で
きる。しかし，これは地下構造の反射面ではなく， 1 ピング前の音波が海面反射して次のピングの受 信信号として現れた結果である。このように真の 信号と多重散乱が混入する場合は, 本フィルター では分離不可能となる。

\section{2 結果と考察}

\subsection{1 音響画像の正規化}

前節の音響データ処理により, ベヨネーズカル デラの白嶺鉱床上の音響画像を作成し， Fig. 12 に示すとおり海底面下 $30 \mathrm{~m}$ までの層状構造を捉 えることが出来た。しかし, Fig. 12 の画像中に は， 1 ピング前の送信波が海面で反射した海面反 射の影響や，ベョネーズカルデラの斜面からの反 


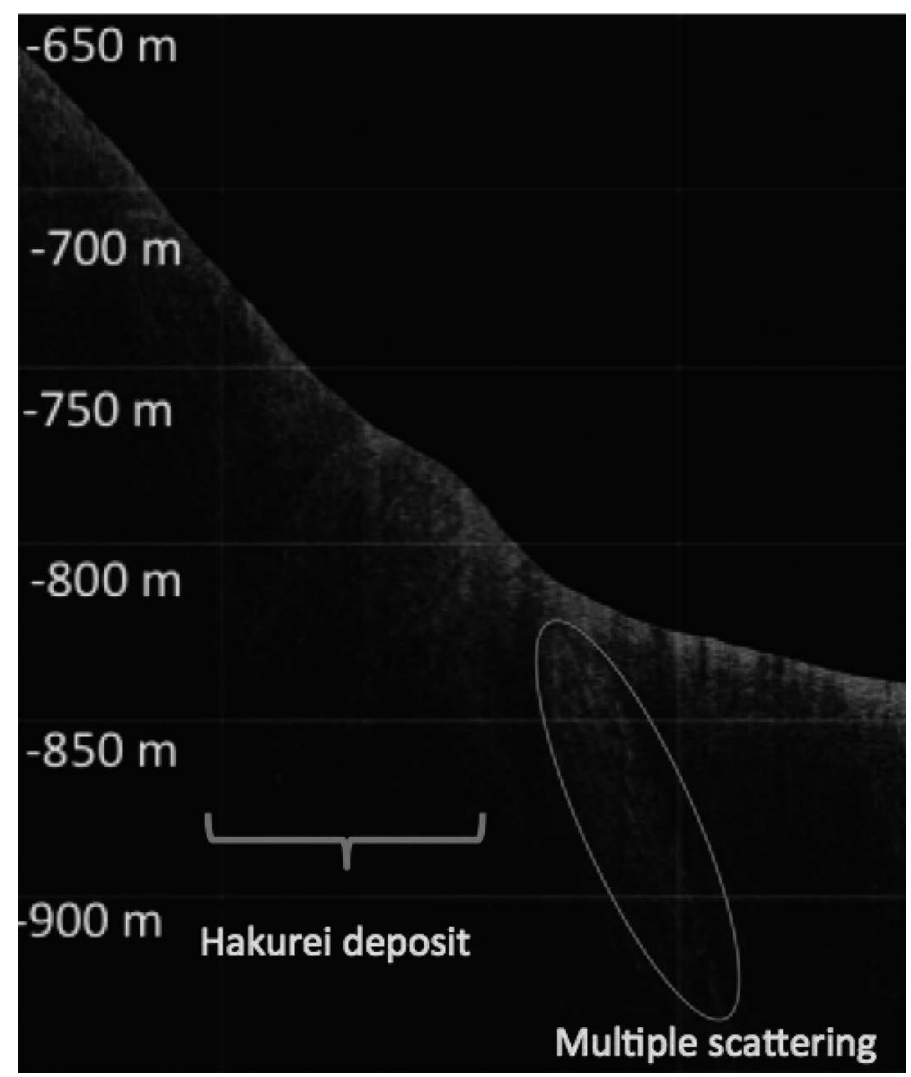

Fig. 12 SBP acoustic profile in the Bayonnaise caldera.

射波の影響などが含まれていることが考えられ る. 最終的にはこれらの信号とノイズの分離を行 う必要があり，フィルタリング手法の評価に対し て SN 比を用いて定量的に議論すべきである。し かし，海中の反射面を特定することは非常に困難 である，そこで，まずは多重散乱によるノイズの 影響範囲の把握が必要と考え, ピングごとに多重 散乱の影響が大きいエリア，小さいエリアを定量 的に示す試みを行った。 まず，1 パルスごとのレ ンジ方向(鉛直方向)の反射強度を積算し, 1 パル スの擬似的なエネルギーの総計とみなしてその分 布を見れば，多重散乱などによって混入した別の 信号がある場所は，平均值よりも高くなることが 予想される。 そこで, Fig. 12 と同じ範囲に対し て反射強度の総計(積算強度と呼ぶ）を以下の手 順で行った.

・レンジ方向の音響断面から正の領域のピーク值
をつなげた包絡線を求める

・各ピングの包絡線の断面積を求める

・断面積を画像全体の最大值で割る

・SBP 曳航体からの距離の減衰を考慮するため に上で求めた值に SBP 曳航体の高度を乗じ, $\mathrm{SBP}$ 曳航体の高度の最大值 $(100 \mathrm{~m})$ で正規化す る

この結果を Fig. 13 に示す. SBP 曳航体の高度補 正を行うことによってピークが出現しているが, これらは，Fig. 12 に示すべョネーズカルデラの 東側斜面の多重散乱の場所と一致しており, 斜面 からの多重散乱によって発生するノイズの位置を 特定できる可能性が示唆される.

\subsection{2 ノイズ除去の考察}

今後新たな熱水鉱床を発見するために音響画像 のノイズの除去による海底地層の明瞭化を行うた めに 3 つのノイズ除去を行った. まず, 他の機 


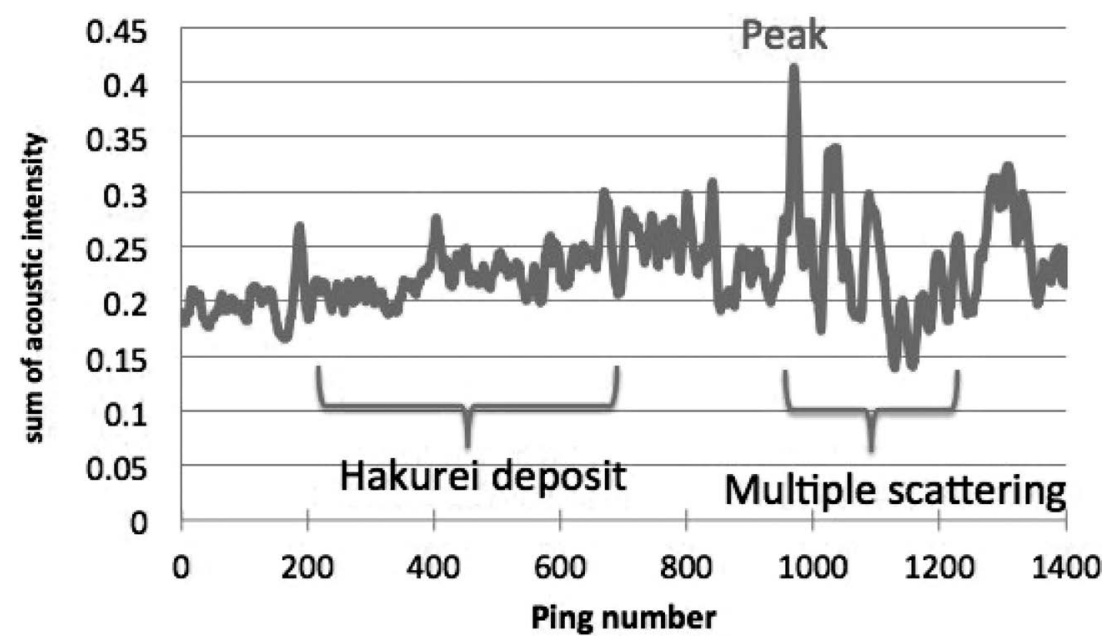

Fig. 13 Diagram of the sum of the acoustic intensity normalized by SBP height in the range direction.

器の信号が混入した場合の除去 (チャネル合成), 次に送信器自身が発生する SBP 曳航体の進行方 向に平行な残響ノイズの除去 (ストライプ残響補 正), 最後に多重散乱の低減処理(音波の減衰を用 いたフィルタリング)によってノイズの低減化を 行った.

本研究で観測を行ったベヨネーズカルデラの東 側斜面の地形の傾斜の変化に伴う多重散乱が海底 下 $100 \mathrm{~m}$ まで発生している. 発生するポイントは, 3.2.1の SBP 曳航体の高度補正を施した積算強度 分布により特定することはできる。しかし，例え ば, 3.1 .5 で行った多重散乱低減処理を適用する と深いエリアのノイズは低減可能であるが，浅い エリアのノイズは真の信号も距離で一様にフィル タリングするため, 信号とノイズの分離が非常に 困難である，今後は，作成画像単体からではなく 複数の情報 (海底地形, 形状 - 強度 - 距離の違い, SBP 曳航体の姿勢情報, 他のセンサー情報など） を用いて多角的に多重散乱の特徵の抽出を行い, 信号との分離を行う必要があると考える.

\section{4. まとめ}

本研究では，SBP 曳航体の開発および SBP 曳 航体による伊豆小笠原諸島のベヨネーズカルデラ の音波観測を行った。
海底熱水鉱床の観測に特化した SBP 曳航体の 開発を行い，実際の熱水鉱床に対して観測を実施 した結果, 海底下 $30 \mathrm{~m}$ までの層状構造を捉える ことができた、ただし，既存の海底熱水鉱床であ るベヨネーズ海丘カルデラの白嶺鉱床でも音響断 面マップを作成したが, 海底熱水鉱床特有の地質 構造は, 確認できなかった。 しかし, 深海におけ る音響断面マップによって海底下の地質構造が得 られたことは, 同様のカルデラにおける適用が可 能となったことを示している，今後, ハード面や ソフト面, 運用面でのさまざまな微調整を行う必 要があるが, 本システムは, 本研究グループで開 発している海洋鉱物資源広域探査システムの中の 手法の 1 つとして十分に機能することが確認でき たと考える.

\section{謝辞}

本研究 (海洋鉱物資源広域探査システム開発プ ロジェクト) は, 文部科学省「海洋資源利用促進 技術開発プログラム」による支援を受けている. また,「海洋エンジニアリング株式会社第七開洋 丸 KKKyot14-03 次航海スタッフ」,「株式会社リ ンク」,「株式会社エス・イー・エイ」の方々から 多大なる支援をいただいた。ここに深く感謝の意 を表する。 


\section{参考文献}

1）首相官邸資料，海洋基本計画，http://www. kantei.go.jp/jp/singi/kaiyou/kihonkeikaku/ 130426gaiyou.pdf (最終検索日：2016/03/30)

2) Z. Ben-Avraham, T. M. Neimi, D. Neev, J. K. Hall and Y. Levy, "Distribution of Holocene sediments and neotectonics in the deep north basin of the Dead Sea," Mar. Geol., 113, 219231 (1993).

3）片山肇, 坂木拓也, "日本海東部, 秋田沖 における堆積速度の広域分布, " 地学雑誌, 113 (10), 505-518 (2007).

4）内田康人, "北海道沿岸域にて実施された 海底音波探査とその記録解析, " 地質研究所 ニュース, 590, 505-518 (1999).

5）明治大学ガスハイドレート研究所, 2014 年度 調查概要, http://www.kisc.meiji.ac.jp/`hydrate/ images/summary201501.pdf (最終検索日： 2016/03/30)
6）多良賢二, 徳山英一, 芦寿一郎, 亀尾 桂, "深海曳航式サブボトムプロファイラーによ る熱水活動域の地下浅部構造の解明一中部沖 縄トラフ伊是名海穴の例, " 日本地質学会第 120 年学術大会講演要旨, 76-76 (2013).

7）土屋利雄, 中西俊之, 網谷泰孝, "しんかい 2000 用サブボトムプロファイラーの開発, " 海洋科学技術センター試験研究報告, 15, 11-22 (1985).

8）産業技術総合研究所, 海陸接合物理探査研究 海域地質環境調査確証技術開発成果報告書, 245-299 (2014).

9) 海洋音響学会, 海洋音響の基礎と応用(成山 堂書店, 東京, 2004), pp. 176-182.

10）棚橋道郎, 塩川 智, 村山信行, 高取亮一, "伊豆・小笠原弧背弧リフト帯ベヨネーズ海 丘で発見された大規模海底熱水鉱床, " 資源 地質, 56(2), 185-196 (2006). 